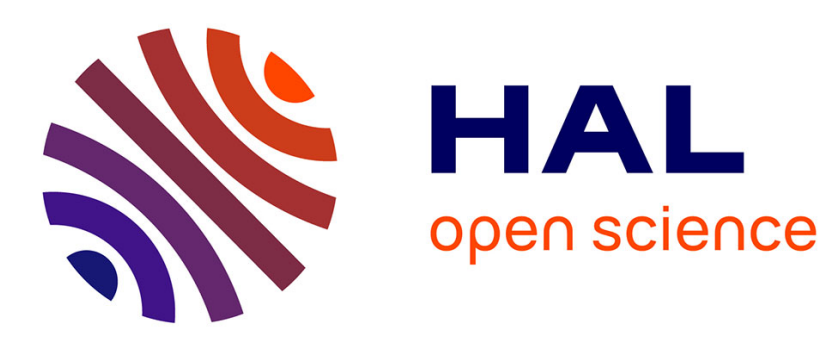

\title{
Physiology and pathology of somatostatin in the mammalian retina: A current view
}

Davide Cervia, Giovanni Casini, Paola Bagnoli

\section{To cite this version:}

Davide Cervia, Giovanni Casini, Paola Bagnoli. Physiology and pathology of somatostatin in the mammalian retina: A current view. Molecular and Cellular Endocrinology, 2008, 286 (1-2), pp.112. 10.1016/j.mce.2007.12.009 . hal-00531974

\section{HAL Id: hal-00531974 \\ https://hal.science/hal-00531974}

Submitted on 4 Nov 2010

HAL is a multi-disciplinary open access archive for the deposit and dissemination of scientific research documents, whether they are published or not. The documents may come from teaching and research institutions in France or abroad, or from public or private research centers.
L'archive ouverte pluridisciplinaire HAL, est destinée au dépôt et à la diffusion de documents scientifiques de niveau recherche, publiés ou non, émanant des établissements d'enseignement et de recherche français ou étrangers, des laboratoires publics ou privés. 


\section{Accepted Manuscript}

Title: Physiology and pathology of somatostatin in the mammalian retina: A current view

Authors: Davide Cervia, Giovanni Casini, Paola Bagnoli

PII: $\quad$ S0303-7207(07)00472-8

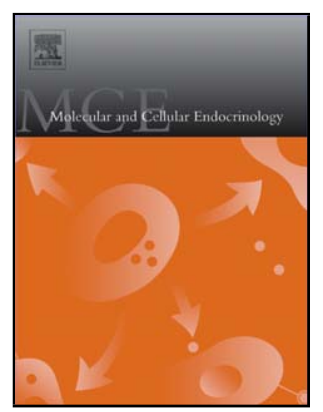

DOI: doi:10.1016/j.mce.2007.12.009

Reference: MCE 6771

To appear in: Molecular and Cellular Endocrinology

Received date: 25-5-2007

Revised date: $11-10-2007$

Accepted date: $12-12-2007$

Please cite this article as: Cervia, D., Casini, G., Bagnoli, P., Physiology and pathology of somatostatin in the mammalian retina: A current view, Molecular and Cellular Endocrinology (2007), doi:10.1016/j.mce.2007.12.009

This is a PDF file of an unedited manuscript that has been accepted for publication. As a service to our customers we are providing this early version of the manuscript. The manuscript will undergo copyediting, typesetting, and review of the resulting proof before it is published in its final form. Please note that during the production process errors may be discovered which could affect the content, and all legal disclaimers that apply to the journal pertain. 


\section{Physiology and pathology of somatostatin in the mammalian retina: a current view}

Davide Cervia $^{\text {a,b }}$, Giovanni Casini ${ }^{\text {a }}$, Paola Bagnoli ${ }^{\text {b,* }}$

${ }^{a}$ Department of Environmental Sciences, University of Tuscia, largo dell'Università snc, blocco D, 01100 Viterbo, Italy

${ }^{b}$ Department of Biology - Unit of General Physiology, University of Pisa, via San Zeno 31, 56127 Pisa, Italy

*Corresponding author:

Prof. Paola Bagnoli, PhD

ph: +39-050-2211422; fax: +39-050-2211421; e-mail: pbagnoli@biologia.unipi.it 


\begin{abstract}
:
In the retina, peptidergic signalling participates in multiple circuits of visual information processing. The neuropeptide somatostatin (SRIF) is localised to amacrine cells and, in some instances, in a subset of ganglion cells. The variegated expression patterns of SRIF receptors $\left(\mathrm{sst}_{1}-\mathrm{sst}_{5}\right)$ and the variety of signalling mechanisms activated by retinal SRIF suggest that this peptide may exert multiple actions on retinal neurons and on retinal physiology, although our current understanding reflects a rather complicated picture. SRIF, mostly through sst $_{2}$, may act as a positive factor in the retina by regulating retinal homeostasis and protecting neurons against damage. In this respect, SRIF analogues seem to constitute a promising therapeutic arsenal to cure different retinal diseases, as for instance ischemic and diabetic retinopathies. However, further investigations are needed not only to fully understand the functional role of the SRIF system in the retina but also to exploit new chemical space for drug-like molecules.
\end{abstract}

Keywords: somatostatin receptors; signalling mechanisms; somatostatin analogues; retinal ischemia; diabetic retinopathy.

\title{
Contents
}

1. Retina and neuropeptides

2. The somatostatinergic system in the retina

2.1. Expression of somatostatin

2.2. Expression of somatostatin receptors

2.3. Signalling mechanisms

2.3.1. Signalling mechanisms in the retina

2.4. Functional role

2.4.1. Somatostatin control of its own release

2.4.2. Somatostatin control of dopamine release

2.4.3. Somatostatin control of glutamate release

2.4.4. Somatostatin effects on other neurotransmitters

3. The somatostatinergic system in retinal diseases

3.1. Retinal ischemia

3.2. Diabetic retinopathy

4. Conclusion

Acknowledgements

References 


\section{Retina and neuropeptides}

The defined input of the mammalian retina, its discrete output, accessibility, laminar organisation, and small number of principal cell types have promoted an understanding of retinal circuitry and structure-functional relationship. Beside its use for investigations on visual information processing, the mammalian retina has been extensively used as an experimental model of the central nervous system. Indeed, it is part of the central nervous system and it is separated at the same time, allowing easy experimental approaches. In addition, the mammalian retina displays the complexity typical of the brain while having an ordered, layered structure that is conserved throughout its extension (Fig 1). The retina is composed of five principal neuronal cell types, including photoreceptors (the light sensitive cells in the retina), bipolar, horizontal, amacrine, and ganglion cells. A sixth type is that of interplexiform cells, that may be considered an amacrine cell variant. The basic circuitry within the retina directs the flow of visual information from photoreceptors, through bipolar cells, to ganglion cells, which are the only output neurons and with their axons constitute the retinofugal projections to the brain. Two horizontal pathways modulate this flow: one provided by horizontal cells in the outer retina, the other formed by amacrine cells in the inner retina. Horizontal cells are strongly electrically coupled and integrate light signals over a large retinal area. They feedback onto photoreceptors, and contact bipolar cells. Thus, inputs from a large surround region of the retina influence photoreceptors and bipolar responses, providing the bipolar cell with a centre-surround organisation.

The most heterogeneous retinal cell type is that of amacrine cells, which can be divided into numerous populations on the basis of their neurochemical phenotypes. In this regard, a wide variety of neuroactive substances are expressed in the mammalian retina. Over the last three decades, several neuropeptides have been investigated and some knowledge is now available of their potential physiological relevance (Bagnoli et al., 2003). In particular, neuropeptides are principally expressed by populations of sparsely distributed, mostly GABAergic amacrine cells and by some ganglion cells. In contrast, neuropeptide receptors are expressed by variegated retinal cell populations, suggesting that peptidergic signalling participates in multiple circuits of visual information processing. Among neuropeptides, somatostatin, or somatotropin release inhibiting factor (SRIF), has been widely investigated in the retina. SRIF is produced from a single gene in two bioactive products: SRIF-14 and SRIF-28 (Olias et al., 2004). SRIF produces its effects by activating five heptahelical transmembrane G-protein coupled receptors, which have been cloned and named sst $_{1}$ to sst $_{5}$ in accordance with IUPHAR recommendations (Hoyer et al., 1995). Here, we provide a review of the latest advances on the role of SRIF and its receptors in the mammalian retina. 


\section{The somatostatinergic system in the retina}

The expression and the localisation of SRIF and of its receptors (both at mRNA and at protein level) in mammalian retinas has been reviewed in recent years (Casini et al., 2005; Thermos, 2003). There is a general agreement that such a distribution reflects the pleiotropic functions of retinal SRIF as a result of the multiple signalling actions of its receptors.

\subsection{Expression of somatostatin}

In general, SRIF immunoreactivity is localised to sparsely distributed, wide-field amacrine and/or displaced amacrine cells and, in some instances, in a subset of ganglion cells. In particular, in the mouse (Cristiani et al., 2002), rat (Larsen et al., 1990; Sagar et al., 1985), guinea pig (Spira et al., 1984; Tornqvist et al., 1982) and human retina (Tornqvist and Ehinger, 1988), SRIF-containing cells are detected in both the inner nuclear layer and the ganglion cell layer. In the mouse retina, the population of SRIF-containing amacrine cells is sparsely distributed to all retinal regions, while the population of displaced amacrine cells is confined to the ventral retina (Cristiani et al., 2002). In the rabbit, cat and primate retina, most SRIF immunoreactive cells are displaced amacrine cells that are predominantly distributed to the ventral retina (Engelmann and Peichl, 1996; Rickman et al., 1996; White et al., 1990; Marshak, 1989; Mitrofanis et al., 1989; Sagar and Marshall, 1988; Sagar, 1987). In spite of the very sparse distribution of SRIF somata, SRIF processes extensively arborise in the inner plexiform layer of all retinal regions. A few ganglion cells displaying SRIF immunoreactivity have been reported in the retina of the new world monkey Tupaia belangeri (Engelmann and Peichl, 1996) and of the cat, where these SRIF-immunoreactive ganglion cells have been identified as a small subset of OFF-center alpha ganglion cells, mostly localised to the inferior retina (White and Chalupa, 1991). Finally, a transient population of SRIF-containing ganglion cells has been discovered in the rat retina during postnatal development (Xiang et al., 2001; Fontanesi et al., 1997).

\subsection{Expression of somatostatin receptors}

Immunohistochemical data show that SRIF receptors are expressed by a variety of retinal cell populations. In rat, rabbit and mouse retinas, sst $_{1}$ is predominantly expressed by SRIF-containing amacrine cells (Dal Monte et al., 2003b; Cristiani et al., 2000; Helboe and Moller, 1999). In the rabbit retina, it is also found on all the dopaminergic amacrine cells (Cristiani et al., 2000). Of the two $\mathrm{sst}_{2}$ isoforms, $\mathrm{sst}_{2 \mathrm{~A}}$ has been localised in rat, rabbit and mouse retinas, where it displays slightly different patterns (Cristiani et al., 2002; Petrucci et al., 2001; Vasilaki et al., 2001; Fontanesi et al., 
2000; Helboe and Moller, 1999; Johnson et al., 1999; Johnson et al., 1998). In the rat retina, sst $2 \mathrm{~A}$ has been localised to amacrine cells, including tyrosine hydroxylase-containing amacrine cells, to rod and cone bipolar cells and to horizontal cells (Johnson et al., 1999). In rabbits, these receptors are expressed mainly by rod bipolar and by sparsely distributed amacrine cells that have been reported to lack (Johnson et al., 1998) or to partially express (Fontanesi et al., 2000) tyrosine hydroxylase immunoreactivity. In the mouse retina, $\mathrm{sst}_{2 \mathrm{~A}}$ immunoreactivity has been reported in rod bipolar cells, horizontal cells, and in amacrine cells (Fig 2), including glycinergic amacrine cells and the population of tyrosine hydroxylase-containing, dopaminergic amacrine cells (Cristiani et al., 2002). The $\mathrm{sst}_{2 \mathrm{~B}}$ isoform in the rat retina is predominantly found on the membrane of photoreceptors, indicating SRIF actions in the outer retina (Vasilaki et al., 2001). In the human retina, both $\mathrm{sst}_{1}$ and $\mathrm{sst}_{2 \mathrm{~A}}$ have been immunohistochemically localised throughout all retinal layers (Klisovic et al., 2001; van Hagen et al., 2000) and in endothelial cells of retinal blood vessels (Klisovic et al., 2001) of the human retina. Regarding $\mathbf{s s t}_{4}$, it has been identified with immunohistochemistry in sparse ganglion cells of the mouse retina (Cristiani et al., 2002). Finally, sst $_{5}$ has been recently reported in cholinergic, dopaminergic and SRIF-containing amacrine cells and in putative ganglion cells of the rat retina (Ke and Zhong, (2007). These data appear to be in contrast with a previous work reporting lack of sst $_{5}$ immnuoreactivity in the rat retina (Vasilaki et al., 2002). Data concerning the retinal localization of sst $_{3}$ are not available, however its mRNA has been detected in rat (Mori et al., 1997), mouse (Cristiani et al., 2002), and human (Klisovic et al., 2001; van Hagen et al., 2000) retinas.

Profound alterations of the levels of SRIF expression as well as of that of specific ssts have been detected in retinas of mice in which $\mathrm{sst}_{1}$ or $\mathrm{sst}_{2}$ genes are genetically deleted (Casini et al., 2004; Dal Monte et al., 2003b). In particular, although changes in the expression of SRIF mRNA have not been reported in these knock-out $(\mathrm{KO})$ retinas, sst $_{1}$ deletion causes an increased content of SRIF peptide, whereas SRIF content decreases after $\mathbf{s s t}_{2}$ loss. In addition, $\mathrm{sst}_{1}$ and $\mathrm{sst}_{2}$ have been found to compensate for each other. Indeed, as a consequence of sst $_{1}$ deletion, sst $_{2}$ becomes overexpressed, whereas in sst $_{2} \mathrm{KO}$ retinas, sst $_{1}$ expression is drastically increased. The fact that SRIF binding sites in sst $_{1} \mathrm{KO}$ retinas have a density similar to that of wild-type (WT) retinas suggests that the relative proportion of SRIF receptors does not change as a consequence of $\mathrm{sst}_{1}$ deletion and indicates that the loss of sst $_{1}$ can be totally compensated by an increase in sst $_{2}$. Compensatory mechanisms at the level of SRIF receptor density also occur in the absence of SRIF since an upregulation of SRIF binding sites has been recently reported in SRIF KO mouse retinas (Mastrodimou et al., 2006b). In addition, in these retinas, all SRIF receptor mRNAs, with the only exception of $\mathrm{sst}_{4} \mathrm{mRNA}$, are expressed at significantly higher levels than in WT retinas (Casini et al., 2005). 


\subsection{Signalling mechanisms}

It is generally accepted that the pleiotropic cellular functions of SRIF are a result on the one hand of the widespread distribution of the SRIF system, and on the other of the variety of signalling mechanisms activated by SRIF receptors (Cervia and Bagnoli, 2007). In particular, as summarised in Table 1, SRIF receptor activation leads to the modulation of different signalling elements, including adenylyl cyclase, guanylyl cyclase, phospholipase $\mathrm{C}$, phospholipase $\mathrm{A}_{2}$, nitric oxide, $\mathrm{K}^{+}$ and $\mathrm{Ca}^{2+}$ channels, $\mathrm{Na}^{+} / \mathrm{H}^{+}$exchanger, phosphatases, mitogen-activated kinases and phosphatidylinositol 3 kinases (Cervia and Bagnoli, 2007; Cervia et al., 2005b). These data have been collected mainly over the last decade using in vitro systems of recombinant and/or native models. In addition, different SRIF analogues may induce distinct conformations of the receptor/ligand complex, preferentially coupled to receptor signalling (Tulipano and Schulz, 2007). For these reasons, our current understanding of receptor subtype-selective signalling reflects a rather complicated picture and parallels between these data and the real in vivo conditions are not so obvious.

\subsubsection{Signalling mechanisms in the retina}

At present, little is known about SRIF signalling in the mammalian retina. For instance, SRIF inhibits adenylyl cyclase activity in the sheep retina (Colas et al., 1992). In contrast, it increases adenylyl cyclase activation in amacrine cells of the rat retina (Feigenspan and Bormann, 1994). Where the specific receptor subtype involved has been studied, it has been found that $\mathrm{sst}_{2}$ inhibits adenylyl cyclase activity in the mouse, probably through $\mathrm{G}_{\mathrm{o \alpha}}$-proteins (Pavan et al., 2004). sst ${ }_{2}$ coupling to $\mathrm{G}_{\mathrm{o \alpha}}$-proteins has been also demonstrated in the rabbit retina (Vasilaki et al., 2003). Interestingly, in the mouse retina, sst $_{1}$ inhibits adenylyl cyclase activity only after elimination of the sst $_{2}$ response, suggesting that there may be interactions between sst $_{1}$ and sst $_{2}$ when they signal via adenylyl cyclase (Pavan et al., 2004). In addition, although NADPH diaphorase staining does not colocalise with $\mathrm{sst}_{1}, \mathrm{sst}_{2}$ or $\mathrm{sst}_{4}$ in the mouse retina (Mastrodimou et al., 2006b), the colocalisation of sst $_{2}$ with NADPH diaphorase in rod bipolar cells and photoreceptor cells of both rat and rabbit retinas has been reported (Vasilaki et al., 2001), suggesting a role of SRIF in the regulation of nitric oxide. Consistently, sst $_{2}$ activates nitric oxide synthase in human retinal pigment epithelial cells (Vasilaki et al., 2004) and in the rat retina (Vasilaki et al., 2002). Once generated, nitric oxide does not exert its effect via specific receptors but it diffuses across synaptic membranes to activate soluble guanylate cyclase, thus increasing intracellular levels of cGMP. Accordingly, in the rat 
retina, $\mathbf{s s t}_{2}$ has been recently shown to mediate SRIF-induced increase of cGMP levels (Mastrodimou et al., 2006a). Regarding the control of $\mathrm{K}^{+}$and $\mathrm{Ca}^{2+}$ conductances, SRIF, acting at $\mathrm{sst}_{2}$, induces a prominent inhibition of large-conductance, $\mathrm{Ca}^{2+}$ - and voltage-dependent $\mathrm{K}^{+}$channels as well as an inhibition of $\mathrm{K}^{+}$-induced increase of the intracellular $\mathrm{Ca}^{2+}$ concentration $\left(\left[\mathrm{Ca}^{2+}\right]_{\mathrm{i}}\right)$ in rod bipolar cells isolated from the rabbit retina (Petrucci et al., 2001). sst $_{2}$ negative coupling to $\mathrm{K}^{+}$ conductances has been also demonstrated also in rod bipolar cells isolated from the mouse retina (Bigiani et al., 2004). In the same experimental model, $\mathrm{sst}_{2}$ inhibits the $\mathrm{K}^{+}$-induced increase of $\left[\mathrm{Ca}^{2+}\right]_{\mathrm{i}}$ both in the cell body and in the axonal terminals (Casini et al., 2005). Similarly, in the axonal terminals of rod bipolar cells isolated from the rat retina, SRIF strongly inhibits a $\mathrm{K}^{+}$induced increase of $\left[\mathrm{Ca}^{2+}\right]_{\mathrm{i}}$ via L-type $\mathrm{Ca}^{2+}$ channels (Johnson et al., 2001). This effect of SRIF is likely to be mediated by $\mathrm{sst}_{2}$ receptors.

\subsection{Functional role}

The first observations of SRIF effects on mammalian retinal physiology reported an influence of the peptide on the amplitude of the ERG b-wave in the rabbit retina in vivo (Cunningham and Neal, 1983), while some years later Zalutsky and Miller (1990), working with rabbit eyecup preparations, found that application of low concentrations of SRIF affects the amplitude of the a-, b- and c-waves. In their seminal work, Zalutsky and Miller also investigated the effects of SRIF application on the activity of different retinal cell types, demonstrating that SRIF actions are characterised by slow onset and long latency and providing the first account of the complexity of SRIF functional actions in the retina. Briefly, SRIF was observed to directly affect bipolar, amacrine and ganglion cells and to influence the horizontal cell network. In particular, all ganglion cell types are excited by SRIF, which also affects the centre-surround balance of their receptive fields.

The localisation of some of the SRIF receptors at locations that are distant from the sites of SRIF release in the inner plexiform layer suggests that this peptide may act in a paracrine fashion. In particular, SRIF functions are likely to result from the actions exerted by SRIF onto other neurotransmitter systems in the retina, including the release of SRIF itself. These effects are consistent with the documented SRIF control of $\mathrm{K}^{+} / \mathrm{Ca}^{2+}$ conductances as well as the nitric oxide/cGMP pathway, which has been recently coupled to neurotransmission in the inner retina (Ding and Weinberg, 2007). In addition, at the level of outer retina, SRIF coupling to $\mathrm{Ca}^{2+}$ dependent mechanisms provides important regulation of both rod and cone photoreceptor function, including transduction and synaptic transfer of light stimuli. In particular, in the outer segment, $\mathrm{Ca}^{2+}$ controls photoreceptor light adaptation, while in the inner segment and synaptic terminal, $\mathrm{Ca}^{2+}$ is 
involved in the regulation of cellular metabolism, glutamate release, cytoskeletal dynamics, gene expression and cell death (Krizaj and Copenhagen, 2002).

\subsubsection{Somatostatin control of its own release}

SRIF may regulate its own release through $\mathrm{sst}_{1}$ in different systems, including the retina (Thermos et al., 2006). In particular, the observation that sst $_{1}$ is expressed by all SRIF-containing amacrine cells strongly suggests that $\mathrm{sst}_{1}$ acts as an autoreceptor to limit SRIF release. Indeed, functional studies in rat retinal explants firmly established that sst $_{1}$ activation decreases SRIF release (Thermos et al., 2006; Mastrodimou and Thermos, 2004). Additional, although indirect, evidence of the autoreceptor function of $\mathrm{sst}_{1}$ derives from studies in $\mathrm{sst}_{1}$ or $\mathrm{sst}_{2} \mathrm{KO}$ mouse retinas. As mentioned above, sst $_{1} \mathrm{KO}$ retinas are characterised by increased levels of SRIF peptide, while sst $_{2} \mathrm{KO}$ retinas display a significant decrease of retinal SRIF. These observations suggest that the amount of retinal SRIF is likely to depend on the expression levels of sst $_{1}$ (Casini et al., 2004): in the absence of sst $_{1}$ (as in sst $_{1} \mathrm{KO}$ retinas) inhibitory mechanisms limiting SRIF levels in the retina would be removed, while in the presence of sst $_{1}$ over-expression (as in $\mathrm{sst}_{2} \mathrm{KO}$ retinas) such mechanisms would be strengthened. Finally, a recent investigation suggests that sst $_{5}$ may also act as an autoreceptor on amacrine cells of the rat retina (Ke and Zhong, 2007), although this hypothesis still needs functional demonstration.

\subsubsection{Somatostatin control of dopamine release}

Based on the expression of SRIF receptors by tyrosine hydroxylase-containing, dopaminergic amacrine cells, SRIF control of dopamine release has been postulated in mouse, rat and rabbit retinas, although there are differences in the individual SRIF receptors that may mediate this control. The direct demonstration of an influence of SRIF on retinal dopamine release has been recently provided by Thermos and colleagues (Kouvidi et al., 2006), who showed that activation of either $\mathrm{sst}_{1}$ or $\mathrm{sst}_{2}$ causes an increase of dopamine release in rat retinal explants, while activation of $\mathrm{sst}_{3}$ has no effect. Since retinal levels of dopamine are known to be positively correlated with light intensity (Boelen et al., 1998; Djamgoz and Wagner, 1992), this SRIF control of dopamine release is likely to have importance for the regulation of light adaptation.

\subsubsection{Somatostatin control of glutamate release}

Glutamate is the major excitatory neurotransmitter in the mammalian retina, and it is implicated in the neurotransmission along the vertical visual pathway from photoreceptors to bipolar cells to ganglion cells. A common trait of the somatostatinergic system among different mammalian retinas 
is the expression of $\mathrm{sst}_{2 \mathrm{~A}}$ in rod bipolar cells, which represent a major source of glutamate in the retina. This observation indicates that an important, conserved functional role of SRIF in the retina is the regulation of glutamate release through an action at $\mathbf{s s t}_{2}$. Consistently, $\mathbf{s s t}_{2}$ activation has been shown to inhibit $\mathrm{K}^{+}$-induced glutamate release in mouse retinal explants (Dal Monte et al., 2003a). In addition, the SRIF-induced inhibition of glutamate release is significantly stronger when sst $_{2}$ is over-expressed, as in $\mathrm{sst}_{1} \mathrm{KO}$ retinas (Bigiani et al., 2004). A further indication that SRIF may limit glutamate release acting at $\mathrm{sst}_{2}$ comes from recent studies where glutamate release was induced by ischemic treatment in a mouse retina preparation in vitro: in these conditions, glutamate release was significantly reduced in $\mathrm{sst}_{1} \mathrm{KO}$ retinas in comparison to WT retinas (Catalani et al., 2007). Together, these data concur to the notion that the SRIF system in the retina is an important regulator of the concentration of released glutamate in the extracellular space. This function is likely to represent an important contribution to the regulation of the glutamatergic transmission along the vertical retinal visual pathway. In addition, by limiting the amount of glutamate available to glutamate receptors, SRIF may also exert an important neuroprotective function against glutamate neurotoxicity that characterises many retinal diseases (see point 3).

\subsubsection{Somatostatin effects on other neurotransmitters}

The localisation of SRIF receptors to different types of amacrine cells in the inner nuclear layer, including glycine containing amacrine cells (Cristiani et al., 2002), some cells likely belonging to subpopulations of GABAergic amacrine cells (Ke and Zhong, 2007; Cristiani et al., 2002), or to horizontal cells, which are considered to be GABAergic (Vardi and Sterling, 1994), suggests that SRIF may participate to the regulation of the retinal levels of these important inhibitory transmitters. Although functional evidence for a SRIF control of glycine release is lacking, SRIF has been suggested to enhance GABAergic transmission through phosphorylation of $\mathrm{GABA}_{\mathrm{A}}$ receptors in amacrine cells of the rat retina (Feigenspan and Bormann, 1994). This possibility is intriguing in view of the fine control that GABAergic amacrine cells exert on transmitter release from rod bipolar cell terminals through $\mathrm{GABA}_{\mathrm{C}}$ receptors (Vaquero and de la Villa, 1999). If these GABAergic amacrine cells respond to a regulation by SRIF, this peptide would be able to control glutamate release by the rod bipolar cells through two distinct mechanisms: a direct action onto the sst $_{2 \mathrm{~A}}$ expressing rod bipolar cells, and an indirect action by regulating GABA release from amacrine cells.

The fact that sst $_{5}$ may be expressed by cholinergic amacrine and displaced amacrine cells (Ke and Zhong, 2007), suggests that SRIF may be involved in the control of acetylcholine release. However, 
earlier investigations showed that SRIF does not change the level of light-evoked release of acetylcholine from rabbit retina (Cunningham and Neal, 1983).

\section{The somatostatinergic system in retinal diseases}

The wide anatomical distribution and multiple actions of SRIF and its receptors have stimulated intense clinical studies, and the SRIF system is currently a therapeutic target for different pathological conditions (Cervia and Bagnoli, 2007; Panteris and Karamanolis, 2005; Weckbecker et al., 2003). SRIF analogues are either peptidic or non-peptidic compounds that equally bind to the majority of SRIF receptors (Armani et al., 2007; Ludvigsen et al., 2007; Nolan et al., 2007; Zatelli et al., 2007; Batista et al., 2006; Cervia et al., 2005a; van der Hoek et al., 2005; van der Hoek et al., 2004; Lewis et al., 2003; Reubi et al., 2002), or are selective for a specific SRIF receptor subtype or class (Cervia et al., 2005b; Olias et al., 2004; Weckbecker et al., 2003). In addition, the emergence of novel multispecific SRIF analogues (compounds targeting different cellular receptors) and conjugates (synthesised by chemically linking SRIF analogues with other agents) with improved receptor specificity may produce a new generation of potential drugs (Dasgupta, 2004). On the basis of laboratory findings, the possible clinical use of SRIF analogues in ophthalmology has been suggested (Casini et al., 2005; Missotten et al., 2005). However, difficulties with the route of administration, dosage, and adverse effects may compromise the translation to the clinics.

\subsection{Retinal ischemia}

Ischemia deprives a tissue of three requirements: oxygen, metabolic substrates, and removal of waste products. The loss of these requirements will initially lower homeostatic responses and with time will induce injury to the tissue due to cell loss by apoptosis (Osborne et al., 2004). Ischemia can be considered as a sort of final common pathway in retinal diseases. It is a primary cause of neuronal death and is a common cause of visual impairment and blindness. To contrast this pathological state, specific pharmacological strategies need to be developed aimed at the many putative cascades generated during ischemia (Osborne et al., 2004). Among pharmacological targets, the SRIF system is a candidate that is being subjected to intensive investigation. Indeed, there is evidence that retinal SRIF may act as a neuroprotective agent in ischemic retinas (Casini et al., 2005). In particular, in guinea pig retinas, octreotide (a long-lasting sst $_{2}$ preferred agonist) protects against ischemia-reperfusion injury (Celiker and Ilhan, 2002) and $\mathbf{s s t}_{2}$ agonists attenuate cell death in rat retinal explants subjected to chemical ischemia (Mastrodimou et al., 2005). Recently, an altered expression of SRIF receptors has been shown to modulate retinal responses to cell damage in an in vitro model of the ischemic mouse retina (Catalani et al., 2007). In particular, 
$\mathrm{sst}_{1} \mathrm{KO}$ retinas, where $\mathrm{sst}_{2}$ are over-expressed and over-functional, display a marked reduction of cell death with respect to WT or $\mathrm{sst}_{2} \mathrm{KO}$ retinas. In addition, the expression of protease caspase-3 mRNA, a marker of apoptotic cell death, is also reduced in $\mathrm{sst}_{1} \mathrm{KO}$ as compared to WT retinas. Taken together, these observations demonstrate that an increased presence/activation of functional sst $_{2}$ protects against retinal ischemia.

Immunohistochemical analyses have identified some of the retinal cell populations that are protected by $\mathrm{sst}_{2}$ activation. In particular, in explants of the rat retina subjected in vitro to chemical ischemia, sst $_{2}$ agonists prevent, at least in part, the loss of several retinal cell populations, including choline acetyltransferase-, tyrosine hydroxylase-, nitric oxide synthase-positive amacrine cells as well as the rod bipolar cells (Mastrodimou et al., 2005). On the other hand, other studies in a model of in vitro ischemia of the mouse retina have recently demonstrated that the extent of sst $_{2}$-mediated protection may vary among different retinal cell populations (Catalani et al., 2007), suggesting a high level of complexity within the neuroprotective mechanisms of $\mathrm{sst}_{2}$. For instance, it is interesting to note that the population of rod bipolar cells, which express sst $_{2}$ at high levels, is severely affected by ischemia, but it is significantly spared in the presence of sst $_{2}$ overexpression, as in $\mathrm{sst}_{1} \mathrm{KO}$ retinas, while it is more heavily damaged in the absence of $\mathrm{sst}_{2}$, as in $\mathrm{sst}_{2} \mathrm{KO}$ retinas (Fig. 3).

It is generally accepted that an important component of ischemic retinal injury involves neuronal depolarisation and increased glutamatergic stimulation. Other factors may also play a part in neuronal susceptibility during ischemia and they include the ability to modulate $\mathrm{Ca}^{2+}$ homeostasis, extracellular $\mathrm{pH}$ and the cells' ability to quench free radicals (Osborne et al., 2004). Regarding the mechanism of action underlying SRIF neuroprotective effects in mouse ischemic retinas, $\mathrm{sst}_{2}$ may act through the involvement of presinaptically $\mathrm{sst}_{2}$-mediated modulation of $\mathrm{K}^{+}$and $\mathrm{Ca}^{2+}$ conductances leading to cell hyperpolarisation, $\left[\mathrm{Ca}^{2+}\right]_{\mathrm{i}}$ decrease and reduction of glutamate release (see paragraph 2.4.3.). $\mathrm{sst}_{2}$ may also regulate, postsinaptically, NMDA receptor activation by glutamate as well as $\mathrm{K}^{+}$and $\mathrm{Ca}^{2+}$ voltage-dependent channels. Neuroprotective effects of SRIF on NMDA-induced neuronal death have been previously shown in rats (Forloni et al., 1997). In addition, in an in vitro model of chemical ischemia of the mouse retina, it has been recently demonstrated that not only retinal glutamate release increases under ischemic conditions (consistent with a role of glutamate excitotoxicity in ischemia-induced neuronal death), but also that this increase is significantly reduced in $\mathrm{sst}_{1} \mathrm{KO}$ retinas, indicating that the protection provided by increased presence of functional $\mathrm{sst}_{2}$ is likely to be mediated by $\mathrm{sst}_{2}$ modulation of glutamate release (Catalani et al., 2007). Other mechanisms may also participate in the protective role of SRIF against retinal ischemia, such as an sst $_{2}$-mediated regulation of nitric oxide, an important mediator in the 
pathogenesis of retinal ischemic damage (Osborne et al., 2004). However, in guinea pig retinas, SRIF analogues do not seem to influence nitric oxide activity, which is decreased as a consequence of retinal ischemia-reperfusion (Celiker and Ilhan, 2002).

\subsection{Diabetic retinopathy}

The concept that ischemia is the driving force for new vessel formation in the retina can be traced back over 50 years (Osborne et al., 2004). Indeed, retinal ischemia is commonly caused by vascular closure with liberation of vasoproliferative factors, which in turn produces neovascularisation. Ocular neovascularisation and the associated hemorrhages and fibrovascular proliferations are the underlying threats to vision in diverse conditions such as diabetic retinopathy, a leading cause of visual loss in industrialised countries. Laser photocoagulation remains the only procedure recommended for severe nonproliferative or proliferative retinopathy (Porta and Allione, 2004), but this is an invasive procedure and provides only temporary protection (Croxen et al., 2004). Less destructive approaches are desirable, and the use of SRIF analogues is currently tested in clinical trials with some success (Boehm, 2007; Palii et al., 2007; Croxen et al., 2004; Sjolie and Moller, 2004).

SRIF levels in the vitreous of patients with diabetic retinopathy are significantly lower than those in nondiabetic control subjects (Hernandez et al., 2005; Simo et al., 2002). This observation suggests that the intravitreous deficit of SRIF may contribute to the process of retinal neovascularisation typical of proliferative retinopathy and supports the concept that adequate levels of SRIF are needed for the maintenance of retinal homeostasis. Furthermore, there is a general agreement that SRIF may contrast neovascularisation associated with diabetic retinopathy, although the mechanism of action remains to be elucidated (Boehm, 2007; Casini et al., 2005). Angiogenesis is a complex process, but it may be regarded as the result of changes in the equilibrium between anti- and proangiogenic factors. For instance, the insulin-like growth factor-1 (IGF-1), stimulated by growth hormone, increases in the vitreous of diabetic retinopathy patients (Simo et al., 2002), and it is a major pro-angiogenic factor (DeBosch et al., 2001). SRIF analogues are powerful inhibitors of growth hormone release and, therefore, decrease the blood IGF-1 concentration. Thus, SRIF may exert its antiangiogenic effects on the retina through antagonism of the growth hormone axis (Boehm, 2007; Wilkinson-Berka et al., 2006; Garcia de la Torre et al., 2002). On the other hand, SRIF may inhibit retinal angiogenesis through autocrine and paracrine effects, perhaps directly on retinal cells or on retinal blood vessels (Boehm, 2007; Baldysiak-Figiel et al., 2004; Dasgupta, 2004; Garcia de la Torre et al., 2002; Higgins et al., 2002). These effects are likely to include regulation of the levels of angiogenesis-associated factors that are expressed in the retina, such as 
IGF-1/IGF-1 receptors and vascular endothelial growth factor (VEGF)/VEGF receptors. In particular, IGF-1 not only is in the blood depending on the levels of circulating growth hormone (see above), but it and its receptors are also expressed throughout the retina in vascular, neuronal and glial cells, and they are altered by hyperglycaemia and hypoxia (Wilkinson-Berka et al., 2006). For instance, the levels of IGF-1 receptor mRNA are increased in the retinas of mouse models of both diabetic retinopathy (Kuang et al., 2003) and hypoxia-induced proliferative retinopathy (Dal Monte et al., 2007), although conflicting results have been reported in rat retinas (Leske et al., 2006; Leske et al., 2004; Averbukh et al., 1998). Regarding the VEGF system, diabetic retinopathy and hypoxia/acidosis-induced proliferative retinopathy have been shown to cause overexpression of retinal levels of VEGF and its receptors, thus increasing microvascular permeability and angiogenesis (Dal Monte et al., 2007; Leske et al., 2004; Werdich et al., 2004; Witmer et al., 2003; McLeod et al., 2002; Witmer et al., 2002; Ellis et al., 2000; Gilbert et al., 1998). In a recent analysis of hypoxia-induced neoangiogenic retinas of $\mathrm{sst}_{1} / \mathrm{sst}_{2} \mathrm{KO}$ mice, we have demonstrated that lack of $\mathrm{sst}_{2}$, as in $\mathrm{sst}_{2} \mathrm{KO}$ retinas, is associated with significantly higher levels of neovascularisation. Moreover, enhanced SRIF function at sst $_{2}$, as in sst $_{1} \mathrm{KO}$ retinas, limits the hypoxia-induced increase of the pro-angiogenic VEGF, whereas sst ${ }_{2}$ loss upregulates this increase (Fig. 4). In addition, the expression of the angiopoietin-1/2 and their receptors, which have different roles in the angiogenetic process, is dysregulated in the absence of sst $_{2}$. (Dal Monte et al., 2007). These observations provide evidence that sst ${ }_{2}$ may be beneficial in limiting hypoxia-induced neovascularisation in the retina (Dal Monte et al., 2007; Kociok et al., 2006; Takagi et al., 2003).

Another mechanism which may underlie anti-angiogenic effects of SRIF includes the involvement of the protein kinase CK2 (formerly casein kinase 2), an ubiquitous serine/threonine protein kinase that is involved in a wide variety of biological processes, including retinal angiogenesis and pathogenesis of diabetic and other proliferative retinal microangiopathies (Ljubimov et al., 2004). Indeed, a cross-talk between sst $_{2}$ and the CK2 pathway has been suggested on the basis that octreotide, combined with CK2 inhibitors, blocks retinal neovascularisation in a mouse model of oxygen-induced retinopathy more efficiently than either compound alone (Kramerov et al., 2006).

\section{Conclusion}

Although far from being fully elucidated, SRIF modulation of ionic conductances, intracellular effectors and transmitter release in the retina may account for the observed effects of SRIF on retinal visual processing. In addition, SRIF may act as a positive factor in the retina by regulating 
retinal homeostasis and protecting neurons against damage. In this respect, SRIF analogues seem to constitute a promising therapeutic arsenal to cure different retinal diseases and their clinical applications are the object of numerous studies. However, further investigations are needed not only to fully understand the functional role of the SRIF system in the retina but also to exploit new chemical space for drug-like molecules.

\section{Acknowledgements}

This work was supported by the Italian Ministry of University and Research (PRIN 2005, grant \# 2005052312). 


\section{References}

Armani, C., Catalani, E., Balbarini, A., Bagnoli, P., Cervia, D., 2007. Expression, pharmacology, and functional role of somatostatin receptor subtypes 1 and 2 in human macrophages. $\mathrm{J}$ Leukoc Biol 81, 845-855.

Averbukh, E., Weiss, O., Halpert, M., Yanko, R., Moshe, R., Nephesh, I., et al., 1998. Gene expression of insulin-like growth factor-I, its receptor and binding proteins in retina under hypoxic conditions. Metabolism 47, 1331-1336.

Bagnoli, P., Dal Monte, M., Casini, G., 2003. Expression of neuropeptides and their receptors in the developing retina of mammals. Histol Histopathol 18, 1219-1242.

Baldysiak-Figiel, A., Lang, G.K., Kampmeier, J., Lang, G.E., 2004. Octreotide prevents growth factor-induced proliferation of bovine retinal endothelial cells under hypoxia. J Endocrinol $180,417-424$.

Batista, D.L., Zhang, X., Gejman, R., Ansell, P.J., Zhou, Y., Johnson, S.A., et al., 2006. The effects of SOM230 on cell proliferation and adrenocorticotropin secretion in human corticotroph pituitary adenomas. J Clin Endocrinol Metab 91, 4482-4488.

Bigiani, A., Petrucci, C., Ghiaroni, V., Dal Monte, M., Cozzi, A., Kreienkamp, H.J., et al., 2004. Functional correlates of somatostatin receptor 2 overexpression in the retina of mice with genetic deletion of somatostatin receptor 1. Brain Res 1025, 177-185.

Boehm, B.O., 2007. Use of long-acting somatostatin analogue treatment in diabetic retinopathy. Dev Ophthalmol 39, 111-121.

Boelen, M.K., Boelen, M.G., Marshak, D.W., 1998. Light-stimulated release of dopamine from the primate retina is blocked by 1-2-amino-4-phosphonobutyric acid (APB). Vis Neurosci 15, 97-103.

Casini, G., Catalani, E., Dal Monte, M., Bagnoli, P., 2005. Functional aspects of the somatostatinergic system in the retina and the potential therapeutic role of somatostatin in retinal disease. Histol Histopathol 20, 615-632.

Casini, G., Dal Monte, M., Petrucci, C., Gambellini, G., Grouselle, D., Allen, J.P., et al., 2004. Altered morphology of rod bipolar cell axonal terminals in the retinas of mice carrying genetic deletion of somatostatin subtype receptor 1 or 2. Eur J Neurosci 19, 43-54.

Catalani, E., Cervia, D., Martini, D., Bagnoli, P., Simonetti, E., Timperio, A.M., et al., 2007. Changes in neuronal response to ischemia in retinas with genetic alterations of somatostatin receptor expression. Eur J Neurosci 25, 1447-1459.

Celiker, U., Ilhan, N., 2002. Nitric oxide and octreotide in retinal ischemia-reperfusion injury. Doc Ophthalmol 105, 327-338.

Cervia, D., Bagnoli, P., 2007. An update on somatostatin receptor signalling in native systems and new insights on their pathophysiology. Pharmacol Ther, doi:10.1016/j.pharmthera.2007.1006.1010.

Cervia, D., Langenegger, D., Schuepbach, E., Cammalleri, M., Schoeffter, P., Schmid, H.A., et al., 2005a. Binding and functional properties of the novel somatostatin analogue KE 108 at native mouse somatostatin receptors. Neuropharmacology 48, 881-893.

Cervia, D., Nunn, C., Bagnoli, P., 2005b. Multiple signalling transduction mechanisms differentially coupled to somatostatin receptor subtypes: a current view. Curr Enzyme Inhibition 1, 265-279.

Colas, B., Valencia, A.M., Prieto, J.C., Arilla, E., 1992. Somatostatin binding and modulation of adenylate cyclase in ovine retina membranes. Mol Cell Endocrinol 88, 111-117.

Cristiani, R., Fontanesi, G., Casini, G., Petrucci, C., Viollet, C., Bagnoli, P., 2000. Expression of somatostatin subtype 1 receptor in the rabbit retina. Invest Ophthalmol Vis Sci 41, 31913199. 
Cristiani, R., Petrucci, C., Dal Monte, M., Bagnoli, P., 2002. Somatostatin (SRIF) and SRIF receptors in the mouse retina. Brain Res 936, 1-14.

Croxen, R., Baarsma, G.S., Kuijpers, R.W., van Hagen, P.M., 2004. Somatostatin in diabetic retinopathy. Pediatr Endocrinol Rev 1 Suppl 3, 518-524.

Cunningham, J.R., Neal, M.J., 1983. Effect of gamma-aminobutyric acid agonists, glycine, taurine and neuropeptides on acetylcholine release from the rabbit retina. J Physiol 336, 563-577.

Dal Monte, M., Cammalleri, M., Martini, D., Casini, G., Bagnoli, P., 2007. Antiangiogenic role of somatostatin receptor 2 in a model of hypoxia-induced neovascularization in the retina: results from transgenic mice. Invest Ophthalmol Vis Sci 48, 3480-3489.

Dal Monte, M., Petrucci, C., Cozzi, A., Allen, J.P., Bagnoli, P., 2003a. Somatostatin inhibits potassium-evoked glutamate release by activation of the sst(2) somatostatin receptor in the mouse retina. Naunyn Schmiedebergs Arch Pharmacol 367, 188-192.

Dal Monte, M., Petrucci, C., Vasilaki, A., Cervia, D., Grouselle, D., Epelbaum, J., et al., $2003 b$. Genetic deletion of somatostatin receptor 1 alters somatostatinergic transmission in the mouse retina. Neuropharmacology 45, 1080-1092.

Dasgupta, P., 2004. Somatostatin analogues: multiple roles in cellular proliferation, neoplasia, and angiogenesis. Pharmacol Ther 102, 61-85.

DeBosch, B.J., Baur, E., Deo, B.K., Hiraoka, M., Kumagai, A.K., 2001. Effects of insulin-like growth factor-1 on retinal endothelial cell glucose transport and proliferation. J Neurochem 77, 1157-1167.

Ding, J.D., Weinberg, R.J., 2007. Distribution of soluble guanylyl cyclase in rat retina. J Comp Neurol 502, 734-745.

Djamgoz, M.B., Wagner, H.J., 1992. Localization and function of dopamine in the adult vertebrate retina. Neurochem Int 20, 139-191.

Ellis, E.A., Guberski, D.L., Somogyi-Mann, M., Grant, M.B., 2000. Increased H2O2, vascular endothelial growth factor and receptors in the retina of the BBZ/Wor diabetic rat. Free Radic Biol Med 28, 91-101.

Engelmann, R., Peichl, L., 1996. Unique distribution of somatostatin-immunoreactive cells in the retina of the tree shrew (Tupaia belangeri). Eur J Neurosci 8, 220-228.

Feigenspan, A., Bormann, J., 1994. Facilitation of GABAergic signaling in the retina by receptors stimulating adenylate cyclase. Proc Natl Acad Sci U S A 91, 10893-10897.

Fontanesi, G., Casini, G., Thanos, S., Bagnoli, P., 1997. Transient somatostatin-immunoreactive ganglion cells in the developing rat retina. Brain Res Dev Brain Res 103, 119-125.

Fontanesi, G., Gargini, C., Bagnoli, P., 2000. Postnatal development of somatostatin 2A (sst2A) receptors expression in the rabbit retina. Brain Res Dev Brain Res 123, 67-80.

Forloni, G., Lucca, E., Angeretti, N., Chiesa, R., Vezzani, A., 1997. Neuroprotective effect of somatostatin on nonapoptotic NMDA-induced neuronal death: role of cyclic GMP. J Neurochem 68, 319-327.

Garcia de la Torre, N., Wass, J.A., Turner, H.E., 2002. Antiangiogenic effects of somatostatin analogues. Clin Endocrinol (Oxf) 57, 425-441.

Gilbert, R.E., Vranes, D., Berka, J.L., Kelly, D.J., Cox, A., Wu, L.L., et al., 1998. Vascular endothelial growth factor and its receptors in control and diabetic rat eyes. Lab Invest 78, 1017-1027.

Helboe, L., Moller, M., 1999. Immunohistochemical localization of somatostatin receptor subtypes sst1 and sst 2 in the rat retina. Invest Ophthalmol Vis Sci 40, 2376-2382.

Hernandez, C., Carrasco, E., Casamitjana, R., Deulofeu, R., Garcia-Arumi, J., Simo, R., 2005. Somatostatin molecular variants in the vitreous fluid: a comparative study between diabetic patients with proliferative diabetic retinopathy and nondiabetic control subjects. Diabetes Care 28, 1941-1947. 
Higgins, R.D., Yan, Y., Schrier, B.K., 2002. Somatostatin analogs inhibit neonatal retinal neovascularization. Exp Eye Res 74, 553-559.

Hoyer, D., Bell, G.I., Berelowitz, M., Epelbaum, J., Feniuk, W., Humphrey, P.P., et al., 1995. Classification and nomenclature of somatostatin receptors. Trends Pharmacol Sci 16, 86-88.

Johnson, J., Caravelli, M.L., Brecha, N.C., 2001. Somatostatin inhibits calcium influx into rat rod bipolar cell axonal terminals. Vis Neurosci 18, 101-108.

Johnson, J., Wong, H., Walsh, J.H., Brecha, N.C., 1998. Expression of the somatostatin subtype 2A receptor in the rabbit retina. J Comp Neurol 393, 93-101.

Johnson, J., Wu, V., Wong, H., Walsh, J.H., Brecha, N.C., 1999. Somatostatin receptor subtype 2A expression in the rat retina. Neuroscience 94, 675-683.

Ke, J.B., Zhong, Y.M., 2007. Expression of somatostatin receptor subtype 5 in rat retinal amacrine cells. Neuroscience 144, 1025-1032.

Klisovic, D.D., O'Dorisio, M.S., Katz, S.E., Sall, J.W., Balster, D., O'Dorisio, T.M., et al., 2001. Somatostatin receptor gene expression in human ocular tissues: RT-PCR and immunohistochemical study. Invest Ophthalmol Vis Sci 42, 2193-2201.

Kociok, N., Krohne, T.U., Poulaki, V., Joussen, A.M., 2006. Geldanamycin treatment reduces neovascularization in a mouse model of retinopathy of prematurity. Graefes Arch Clin Exp Ophthalmol.

Kouvidi, E., Papadopoulou-Daifoti, Z., Thermos, K., 2006. Somatostatin modulates dopamine release in rat retina. Neurosci Lett 391, 82-86.

Kramerov, A.A., Saghizadeh, M., Pan, H., Kabosova, A., Montenarh, M., Ahmed, K., et al., 2006. Expression of protein kinase CK2 in astroglial cells of normal and neovascularized retina. Am J Pathol 168, 1722-1736.

Krizaj, D., Copenhagen, D.R., 2002. Calcium regulation in photoreceptors. Front Biosci 7, d20232044.

Kuang, H., Zou, W., Liu, D., Shi, R., Cheng, L., Yin, H., et al., 2003. The potential role of IGF-I receptor mRNA in rats with diabetic retinopathy. Chin Med J (Engl) 116, 478-480.

Larsen, J.N., Bersani, M., Olcese, J., Holst, J.J., Moller, M., 1990. Somatostatin and prosomatostatin in the retina of the rat: an immunohistochemical, in-situ hybridization, and chromatographic study. Vis Neurosci 5, 441-452.

Leske, D.A., Wu, J., Fautsch, M.P., Karger, R.A., Berdahl, J.P., Lanier, W.L., et al., 2004. The role of VEGF and IGF-1 in a hypercarbic oxygen-induced retinopathy rat model of ROP. Mol Vis $10,43-50$.

Leske, D.A., Wu, J., Mookadam, M., Chen, Y., Fautsch, M.P., Holmes, J.M., et al., 2006. The relationship of retinal VEGF and retinal IGF-1 mRNA with neovascularization in an acidosis-induced model of retinopathy of prematurity. Curr Eye Res 31, 163-169.

Lewis, I., Bauer, W., Albert, R., Chandramouli, N., Pless, J., Weckbecker, G., et al., 2003. A novel somatostatin mimic with broad somatotropin release inhibitory factor receptor binding and superior therapeutic potential. J Med Chem 46, 2334-2344.

Ljubimov, A.V., Caballero, S., Aoki, A.M., Pinna, L.A., Grant, M.B., Castellon, R., 2004. Involvement of protein kinase CK2 in angiogenesis and retinal neovascularization. Invest Ophthalmol Vis Sci 45, 4583-4591.

Ludvigsen, E., Stridsberg, M., Taylor, J.E., Culler, M.D., Oberg, K., Janson, E.T., et al., 2007. Regulation of insulin and glucagon secretion from rat pancreatic islets in vitro by somatostatin analogues. Regul Pept 138, 1-9.

Marshak, D.W., 1989. Peptidergic neurons of the macaque monkey retina. Neurosci Res Suppl 10, S117-130.

Mastrodimou, N., Kiagiadaki, F., Hodjarova, M., Karagianni, E., Thermos, K., 2006a. Somatostatin receptors (sst2) regulate cGMP production in rat retina. Regul Pept 133, 41-46. 
Mastrodimou, N., Lambrou, G.N., Thermos, K., 2005. Effect of somatostatin analogues on chemically induced ischaemia in the rat retina. Naunyn Schmiedebergs Arch Pharmacol 371, 44-53.

Mastrodimou, N., Thermos, K., 2004. The somatostatin receptor (sst1) modulates the release of somatostatin in rat retina. Neurosci Lett 356, 13-16.

Mastrodimou, N., Vasilaki, A., Papadioti, A., Low, M.J., Hoyer, D., Thermos, K., 2006b. Somatostatin receptors in wildtype and somatostatin deficient mice and their involvement in nitric oxide physiology in the retina. Neuropeptides 40, 365-373.

McLeod, D.S., Taomoto, M., Cao, J., Zhu, Z., Witte, L., Lutty, G.A., 2002. Localization of VEGF receptor-2 (KDR/Flk-1) and effects of blocking it in oxygen-induced retinopathy. Invest Ophthalmol Vis Sci 43, 474-482.

Missotten, T., Baarsma, G.S., Kuijpers, R.W., van der Born, L.I., van der Loos, T., Croxen, R., et al., 2005. Somatostatin-related therapeutics in ophthalmology: a review. J Endocrinol Invest 28, 118-126.

Mitrofanis, J., Robinson, S.R., Provis, J.M., 1989. Somatostatinergic neurones of the developing human and cat retinae. Neurosci Lett 104, 209-216.

Mori, M., Aihara, M., Shimizu, T., 1997. Differential expression of somatostatin receptors in the rat eye: SSTR4 is intensely expressed in the iris/ciliary body. Neurosci Lett 223, 185-188.

Nolan, L.A., Schmid, H.A., Levy, A., 2007. Octreotide and the novel multi-receptor ligand somatostatin receptor agonist pasireotide (SOM230), block the adrenalectomy-induced increase in mitotic activity in male rat anterior pituitary. Endocrinology.

Olias, G., Viollet, C., Kusserow, H., Epelbaum, J., Meyerhof, W., 2004. Regulation and function of somatostatin receptors. J Neurochem 89, 1057-1091.

Osborne, N.N., Casson, R.J., Wood, J.P., Chidlow, G., Graham, M., Melena, J., 2004. Retinal ischemia: mechanisms of damage and potential therapeutic strategies. Prog Retin Eye Res 23, 91-147.

Palii, S.S., Caballero, S., Jr., Shapiro, G., Grant, M.B., 2007. Medical treatment of diabetic retinopathy with somatostatin analogues. Expert Opin Investig Drugs 16, 73-82.

Panteris, V., Karamanolis, D.G., 2005. The puzzle of somatostatin: action, receptors, analogues and therapy. Hepatogastroenterology 52, 1771-1781.

Pavan, B., Fiorini, S., Dal Monte, M., Lunghi, L., Biondi, C., Bagnoli, P., et al., 2004. Somatostatin coupling to adenylyl cyclase activity in the mouse retina. Naunyn Schmiedebergs Arch Pharmacol 370, 91-98.

Petrucci, C., Resta, V., Fieni, F., Bigiani, A., Bagnoli, P., 2001. Modulation of potassium current and calcium influx by somatostatin in rod bipolar cells isolated from the rabbit retina via sst2 receptors. Naunyn Schmiedebergs Arch Pharmacol 363, 680-694.

Porta, M., Allione, A., 2004. Current approaches and perspectives in the medical treatment of diabetic retinopathy. Pharmacol Ther 103, 167-177.

Reubi, J.C., Eisenwiener, K.P., Rink, H., Waser, B., Macke, H.R., 2002. A new peptidic somatostatin agonist with high affinity to all five somatostatin receptors. Eur J Pharmacol 456, 45-49.

Rickman, D.W., Blanks, J.C., Brecha, N.C., 1996. Somatostatin-immunoreactive neurons in the adult rabbit retina. J Comp Neurol 365, 491-503.

Sagar, S.M., 1987. Somatostatin-like immunoreactive material in the rabbit retina: immunohistochemical staining using monoclonal antibodies. J Comp Neurol 266, 291-299.

Sagar, S.M., Marshall, P.E., 1988. Somatostatin-like immunoreactive material in associational ganglion cells of human retina. Neuroscience 27, 507-516.

Sagar, S.M., Marshall, P.E., Landis, D.M., 1985. Immunoreactive somatostatin in the rat retina: light microscopic immunocytochemistry and chromatographic characterization. Brain Res $336,235-242$. 
Simo, R., Lecube, A., Segura, R.M., Garcia Arumi, J., Hernandez, C., 2002. Free insulin growth factor-I and vascular endothelial growth factor in the vitreous fluid of patients with proliferative diabetic retinopathy. Am J Ophthalmol 134, 376-382.

Sjolie, A.K., Moller, F., 2004. Medical management of diabetic retinopathy. Diabet Med 21, 666672.

Spira, A.W., Shimizu, Y., Rorstad, O.P., 1984. Localization, chromatographic characterization, and development of somatostatin-like immunoreactivity in the guinea pig retina. J Neurosci 4, 3069-3079.

Takagi, H., Koyama, S., Seike, H., Oh, H., Otani, A., Matsumura, M., et al., 2003. Potential role of the angiopoietin/tie2 system in ischemia-induced retinal neovascularization. Invest Ophthalmol Vis Sci 44, 393-402.

Thermos, K., 2003. Functional mapping of somatostatin receptors in the retina: a review. Vision Res 43, 1805-1815.

Thermos, K., Bagnoli, P., Epelbaum, J., Hoyer, D., 2006. The somatostatin sst1 receptor: an autoreceptor for somatostatin in brain and retina? Pharmacol Ther 110, 455-464.

Tornqvist, K., Ehinger, B., 1988. Peptide immunoreactive neurons in the human retina. Invest Ophthalmol Vis Sci 29, 680-686.

Tornqvist, K., Uddman, R., Sundler, F., Ehinger, B., 1982. Somatostatin and VIP neurons in the retina of different species. Histochemistry 76, 137-152.

Tulipano, G., Schulz, S., 2007. Novel insights in somatostatin receptor physiology. Eur J Endocrinol 156 Suppl 1, S3-S11.

van der Hoek, J., de Herder, W.W., Feelders, R.A., van der Lely, A.J., Uitterlinden, P., Boerlin, V., et al., 2004. A single-dose comparison of the acute effects between the new somatostatin analog SOM230 and octreotide in acromegalic patients. J Clin Endocrinol Metab 89, 638645.

van der Hoek, J., Waaijers, M., van Koetsveld, P.M., Sprij-Mooij, D., Feelders, R.A., Schmid, H.A., et al., 2005. Distinct functional properties of native somatostatin receptor subtype 5 compared with subtype 2 in the regulation of ACTH release by corticotroph tumor cells. Am J Physiol Endocrinol Metab 289, E278-287.

van Hagen, P.M., Baarsma, G.S., Mooy, C.M., Ercoskan, E.M., ter Averst, E., Hofland, L.J., et al., 2000. Somatostatin and somatostatin receptors in retinal diseases. Eur J Endocrinol 143 Suppl 1, S43-51.

Vaquero, C.F., de la Villa, P., 1999. Localisation of the GABA(C) receptors at the axon terminal of the rod bipolar cells of the mouse retina. Neurosci Res 35, 1-7.

Vardi, N., Sterling, P., 1994. Subcellular localization of GABAA receptor on bipolar cells in macaque and human retina. Vision Res 34, 1235-1246.

Vasilaki, A., Gardette, R., Epelbaum, J., Thermos, K., 2001. NADPH-diaphorase colocalization with somatostatin receptor subtypes sst2A and sst2B in the retina. Invest Ophthalmol Vis Sci 42, 1600-1609.

Vasilaki, A., Georgoussi, Z., Thermos, K., 2003. Somatostatin receptors (sst2) are coupled to Go and modulate GTPase activity in the rabbit retina. J Neurochem 84, 625-632.

Vasilaki, A., Mouratidou, M., Schulz, S., Thermos, K., 2002. Somatostatin mediates nitric oxide production by activating sst(2) receptors in the rat retina. Neuropharmacology 43, 899-909.

Vasilaki, A., Papadaki, T., Notas, G., Kolios, G., Mastrodimou, N., Hoyer, D., et al., 2004. Effect of somatostatin on nitric oxide production in human retinal pigment epithelium cell cultures. Invest Ophthalmol Vis Sci 45, 1499-1506.

Weckbecker, G., Lewis, I., Albert, R., Schmid, H.A., Hoyer, D., Bruns, C., 2003. Opportunities in somatostatin research: biological, chemical and therapeutic aspects. Nat Rev Drug Discov 2, 999-1017. 
Werdich, X.Q., McCollum, G.W., Rajaratnam, V.S., Penn, J.S., 2004. Variable oxygen and retinal VEGF levels: correlation with incidence and severity of pathology in a rat model of oxygeninduced retinopathy. Exp Eye Res 79, 623-630.

White, C.A., Chalupa, L.M., 1991. Subgroup of alpha ganglion cells in the adult cat retina is immunoreactive for somatostatin. J Comp Neurol 304, 1-13.

White, C.A., Chalupa, L.M., Johnson, D., Brecha, N.C., 1990. Somatostatin-immunoreactive cells in the adult cat retina. J Comp Neurol 293, 134-150.

Wilkinson-Berka, J.L., Wraight, C., Werther, G., 2006. The role of growth hormone, insulin-like growth factor and somatostatin in diabetic retinopathy. Curr Med Chem 13, 3307-3317.

Witmer, A.N., Blaauwgeers, H.G., Weich, H.A., Alitalo, K., Vrensen, G.F., Schlingemann, R.O., 2002. Altered expression patterns of VEGF receptors in human diabetic retina and in experimental VEGF-induced retinopathy in monkey. Invest Ophthalmol Vis Sci 43, 849857.

Witmer, A.N., Vrensen, G.F., Van Noorden, C.J., Schlingemann, R.O., 2003. Vascular endothelial growth factors and angiogenesis in eye disease. Prog Retin Eye Res 22, 1-29.

Xiang, Z., Jiang, L., Kang, Z., 2001. Transient expression of somatostatin mRNA in developing ganglion cell layers of rat retina. Brain Res Dev Brain Res 128, 25-33.

Zalutsky, R.A., Miller, R.F., 1990. The physiology of somatostatin in the rabbit retina. J Neurosci 10, 383-393.

Zatelli, M.C., Piccin, D., Vignali, C., Tagliati, F., Ambrosio, M.R., Bondanelli, M., et al., 2007. Pasireotide, a multiple somatostatin receptor subtypes ligand, reduces cell viability in nonfunctioning pituitary adenomas by inhibiting vascular endothelial growth factor secretion. Endocr Relat Cancer 14, 91-102. 


\section{Legends to Figures}

Fig. 1. Schematic representation of the mammalian retina. All the principal neuronal types are depicted. Retinal layers are named on the right. The incoming light (arrow on the lower left) passes through the whole retinal thickness before reaching the photoreceptors (rods and cones). The vertical pathway of visual information processing, together with lateral influences at the level of horizontal cells are also shown.

Fig. 2. $\mathrm{sst}_{2 \mathrm{~A}}$ immunofluorescence in a whole mouse retina showing $\mathrm{sst}_{2 \mathrm{~A}}$ expression by amacrine cells and their processes. The large, intensely labelled cells are tyrosine hydroxylasecontaining, dopaminergic, wide-field amacrine cells. The dense network of immunolabelled processes, localised to the inner plexiform layer, is formed by processes originating from the dopaminergic amacrine cells and from other, smaller amacrine cells containing glycine. Scale bar, $50 \mu \mathrm{m}$.

Fig. 3. Rod bipolar cells immunolabelled with antibodies directed to protein kinase $\mathrm{C}$ in control retinas and in wild-type (WT), $\mathrm{sst}_{1} \mathrm{KO}$ or $\mathrm{sst}_{2} \mathrm{KO}$ retinas subjected to ischemic treatment. Rod bipolar cells are less affected by ischemia in sst $_{1} \mathrm{KO}$ retinas, while they are more severely damaged in $\mathrm{sst}_{2} \mathrm{KO}$ retinas. The sections were counterstained with 4'-6-diamidino2-phenylindole. Scale bar, $20 \mu \mathrm{m}$.

Fig. 4. VEGF immunostaining in control retinas and in wild-type (WT), sst $\mathrm{KO}_{1} \mathrm{KO} \mathrm{sst}_{2} \mathrm{KO}$ retinas subjected to hypoxic treatment. VEGF expression significantly increases both in retinal cells and in retinal blood vessels of WT retinas treated for hypoxia. This increase is attenuated in the presence of $\mathrm{sst}_{2}$ overexpression (as in $\mathrm{sst}_{1} \mathrm{KO}$ retinas), while it is enhanced in the absence of $\mathrm{sst}_{2}$ expression (as in $\mathrm{sst}_{2} \mathrm{KO}$ retinas). Scale bar, $20 \mu \mathrm{m}$. 


\section{Cervia et al., Fig. 1}

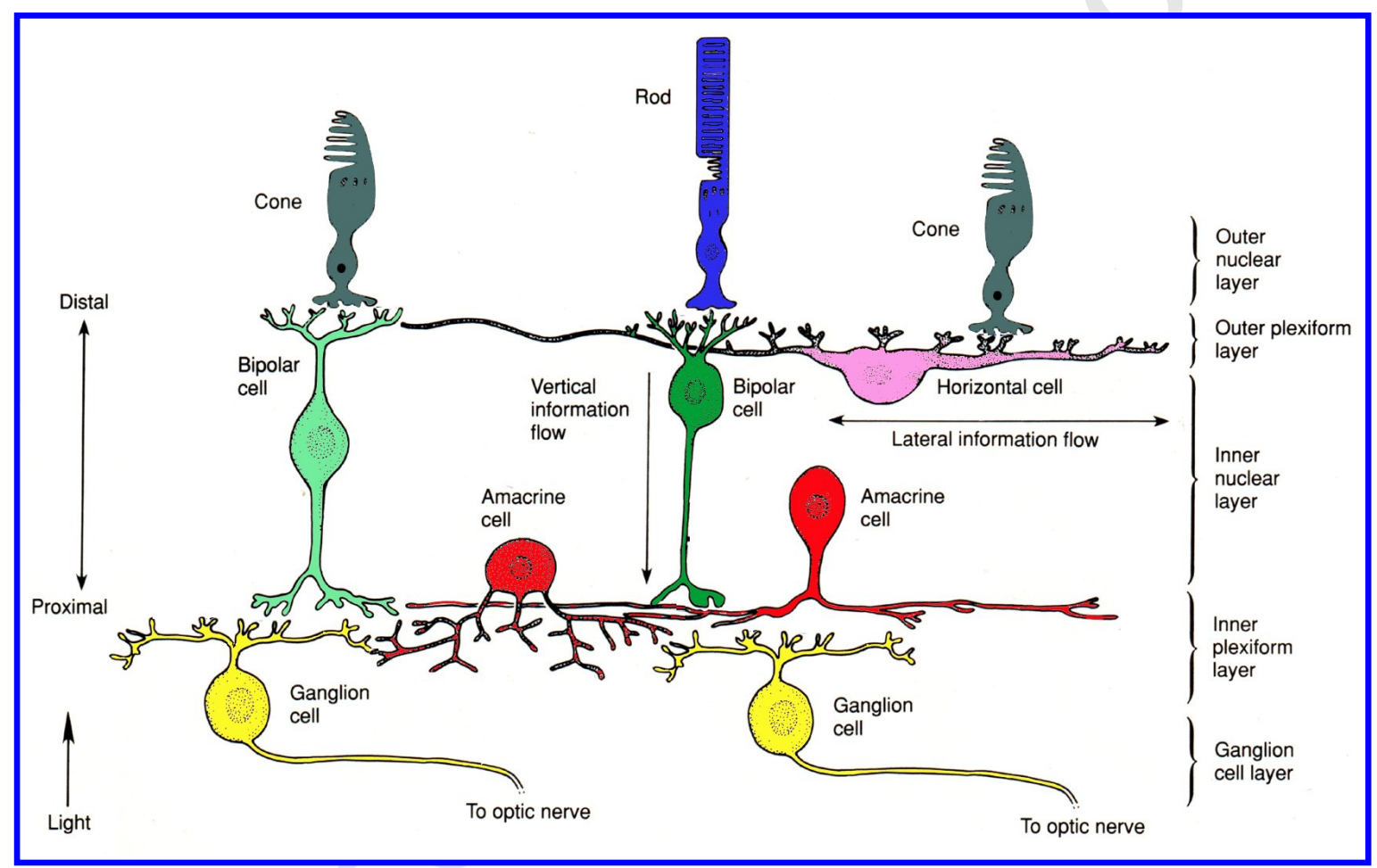




\section{Cervia et al., Fig. 2}

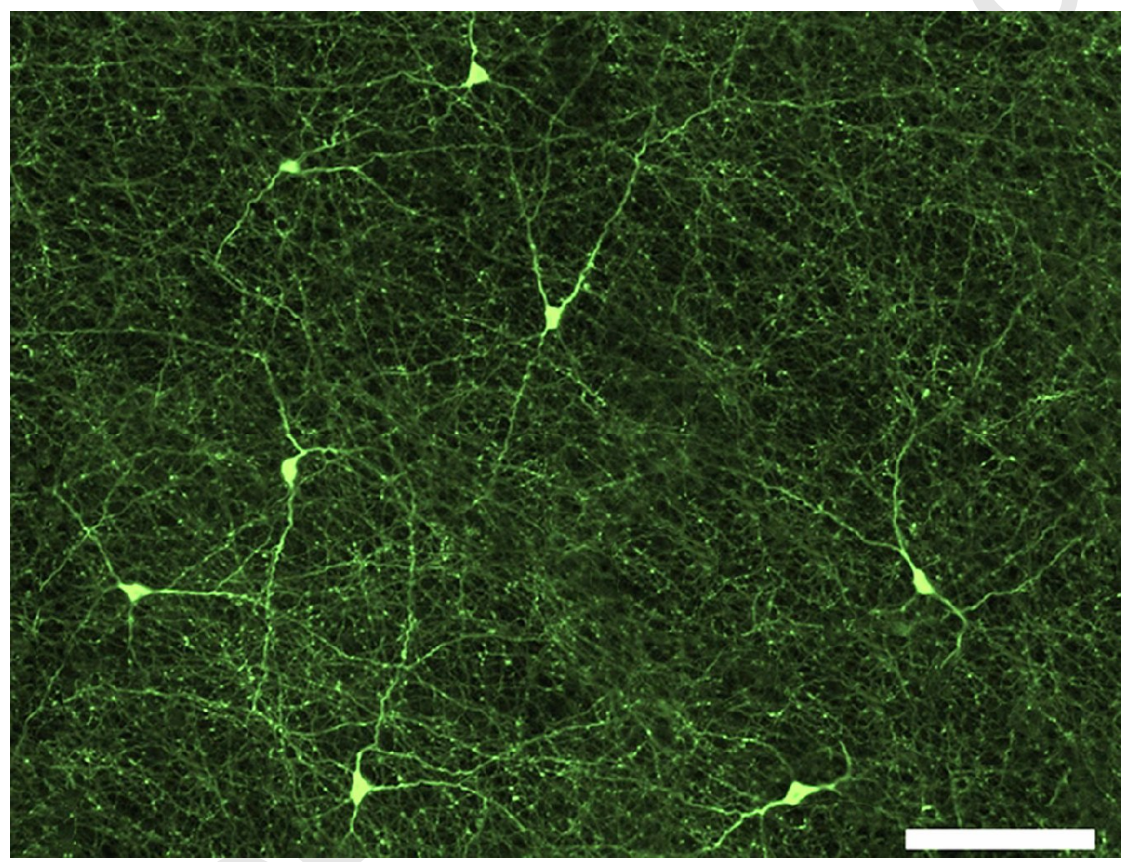

Page 23 of 26 
Cervia et al., Fig. 3
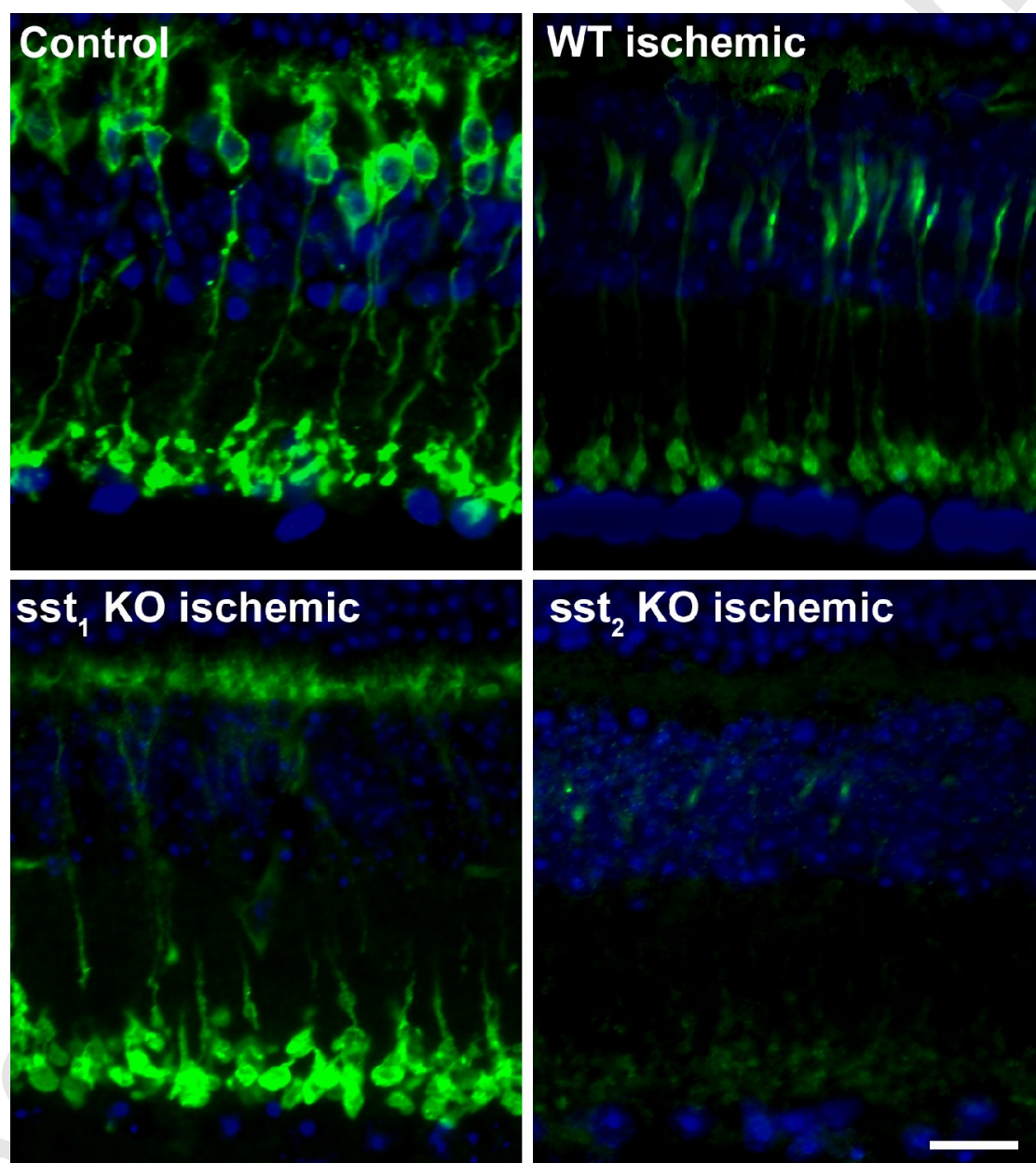

sst $_{2} \mathrm{KO}$ ischemic 
Cervia et al., Fig. 4

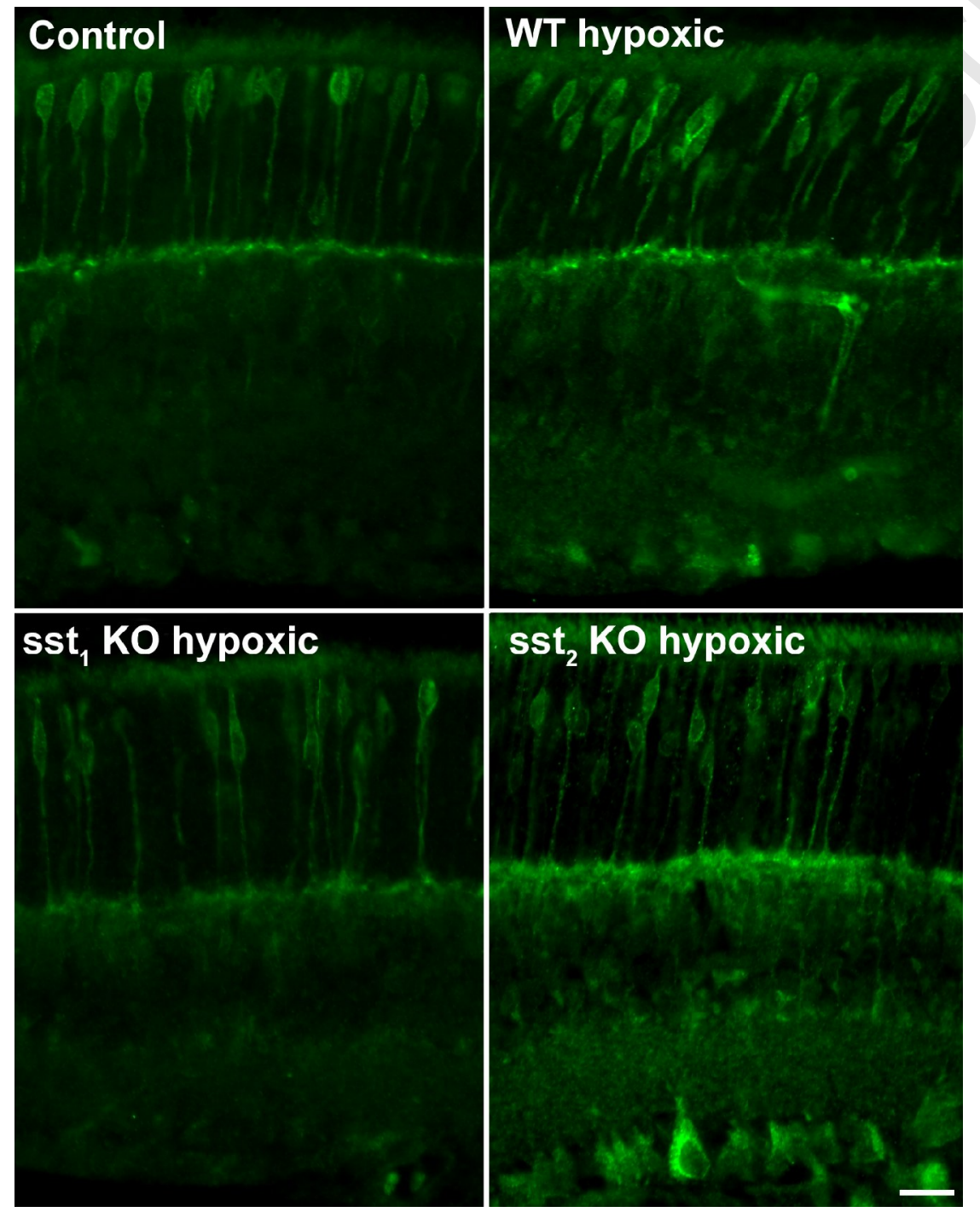


Table 1 Signalling of SRIF and distinct SRIF receptors

\begin{tabular}{|l|c|c|c|c|c|c|}
\hline Signalling elements & SRIF $^{*}$ & sst $_{1}$ & sst $_{2}$ & sst $_{3}$ & sst $_{4}$ & sst $_{5}$ \\
\hline adenylyl cyclase & $\downarrow \uparrow$ & $\downarrow$ & $\downarrow$ & $\downarrow \uparrow$ & $\downarrow$ & $\downarrow \uparrow$ \\
\hline guanylyl cyclase & $\uparrow \downarrow$ & & $\uparrow$ & & & $\downarrow$ \\
\hline phospholipase C & $\downarrow \uparrow$ & $\uparrow$ & $\uparrow$ & $\uparrow$ & $\uparrow$ & $\downarrow \uparrow$ \\
\hline phospholipase $\mathrm{A}_{2}$ & $\downarrow \uparrow$ & $\downarrow$ & $\downarrow \uparrow$ & & $\uparrow$ & $\uparrow$ \\
\hline nitric oxide & $\downarrow \uparrow$ & $\uparrow$ & ${ }_{(?)} \downarrow \uparrow$ & $\downarrow$ & & $\downarrow$ \\
\hline $\mathrm{K}^{+}$channels & $\downarrow \uparrow$ & $\downarrow \uparrow$ & $\downarrow \uparrow$ & $\uparrow$ & $\uparrow$ & $\uparrow$ \\
\hline $\mathrm{Ca}^{2+}$ channels & $\downarrow \uparrow$ & $\downarrow \uparrow$ & $\downarrow \uparrow$ & $\downarrow \uparrow$ & $\uparrow$ & $\downarrow \uparrow$ \\
\hline $\mathrm{Na}^{+} / \mathrm{H}^{+}$exchanger & $\downarrow \uparrow$ & $\downarrow$ & $\downarrow \uparrow$ & $\downarrow$ & $\downarrow \uparrow$ & $(?) \downarrow$ \\
\hline phosphatases & $\uparrow$ & $\uparrow$ & $\uparrow$ & $\uparrow$ & $\uparrow$ & $\uparrow$ \\
\hline mitogen-activated kinases & $\downarrow \uparrow$ & $\downarrow \uparrow$ & $\downarrow \uparrow$ & $\downarrow \uparrow$ & $\uparrow \downarrow \downarrow_{(?)}$ & $\downarrow \uparrow$ \\
\hline phosphatidylinositol 3 kinases & $\downarrow \uparrow$ & $\uparrow$ & $\downarrow \uparrow$ & $\uparrow$ & $\uparrow$ & ${ }_{(?)} \downarrow \uparrow \uparrow_{(?)}$ \\
\hline
\end{tabular}

* when the contribution of the distinct SRIF receptor involved is unknown

(?) when the involvement needs further demonstration

(for ref. see Cervia et al., 2007; Cervia et al., 2005b) 